\title{
An Overview of One Belt and One Road Initiative and the Sustainable Development Concept
}

\author{
Junjie Zhang \\ International Business School \\ Yunnan University of Finance and Economics \\ Kunming, China \\ zhjunjie@foxmail.com
}

\begin{abstract}
The transformation trend of business running around the One Belt One Road countries shows that the concept of sustainable development has gradually gained popularity. This paper focused on identifying the critical issues of sustainability through a literature review to provide supports for its transforming from abstract principles to specific rules. In order to achieve this purpose this paper reviews the emergence of the sustainable development idea and summaries the definitions of the sustainability through examining the previous research work and international documents.
\end{abstract}

Keywords: sustainable development, one belt one road

\section{INTRODUCTION}

The UN Sustainable Development Summit 2015 adopted the 2030 Agenda to provide a framework for national development and international development. China has put forward the "One Belt and One Road" (OBOR) initiative, which is highly in line with the 2030 Agenda as it committed to promote connectivity among countries and common development. The issues of sustainable development is prominent within the regions and industries by the OBOR. The Fourth Silk Road Forum 2018 themed "The Belt and Road Initiative: Promoting Global Sustainable Development". It will focus on open world economy, green and low-carbon development, the new round of technological revolution and inclusive development. The Forum enhanced that OBOR should promotes the prosperity of global trade, overcome the difficulties of economic globalization, balance the world economy, creates new opportunities for protecting the global ecological environment. The Seminar on Advancing sustainable Development Goals with the Belt and Road Cooperation 2019 raised that in order to make the OBOR initiative in line with the principles of sustainable development, a much deeper, faster and more ambitious response is needed to unleash the social and economic transformation needed to achieve the sustainable development [1]. There are thousands of research about how to achieve sustainable development since it was raised, and various principles were built, but it also exposed different problems in the implementation. Some research argued that this concept has vagarious and broad connotation. This paper focused on review the literature of the concept and support to realise the main value and orientation of sustainable development. The review of sustainable development progress and definitions would direct the Chinese enterprises to improve their sustainable development capacity and invest and run business in a sustainable way.

\section{THE CONCEPT OF SUSTAINABLE DEVELOPMENT}

Since the idea of 'sustainability' first appeared in the second half of the twentieth century, it has grown in importance. From the awareness to its practice, sustainability has undergone significant refinement and development to becomes the future direction of human progress. Many international organisations, research institutions and scholars produced and published extensively on sustainable development theory and the outcome of this research will now be examined in detail.

\section{A. The Emergence of Sustainability}

The concepts of sustainability and sustainable development have evolved over the past few decades from the 'environmental friendly' phrase [2]. The initial wave of concern for the environment occurred in the 1960s and 1970s, after the World-War II, western nations achieved rapid economic growth through developing a large-scale economy and accelerating the industrialisation process. People began to express concern over development pattern with its resultant pressure of economic growth, urban expansion, increasing population, overuse of natural resources, environment pollution and other problems[3]. In 1962, the American biologist Rachel Carson described pesticide pollution in her book 'Silent Spring' and triggered a worldwide debate on the questions about human impacts on the natural environment [4]. In 1972, the Club of Rome published the book 'The Limits to Growth' to analyse the relationship between economic development and natural resources through computer modelling, it revealed that the nature resource would not be sufficient for the needs of human beings if the current growth pattern continued [5]. The authors believe that the resources on the planet are limited, and this message is received today by many people [6]. Since then, the concern expressed by the early researchers about the environment and development patterns has led to an almost universal recognition of the concept of sustainability.

The concept of sustainable development is emerging from present-day international efforts in 1972 to 1992 . During the 
period, a series of international conferences and events took place to discuss a range of environmental problems causing growing damages to the ecological environment. The United Nations Conference on the Human Environment was held in Stockholm in 1972, examining the impact of humans on the ecological environment, and achieved a universal consensus on how to preserve the environment around the world[7]. One of the most important outcomes was the Stockholm Declaration which enhanced the global awareness of environmental issues and aided in setting the international environmental policy for the future[8]. This was a significant step towards the concept of sustainable development based upon the relationship between environment and growth. In 1980, the term of 'sustainable development' was referred to by the International Union for Conservation of Nature and Natural Resource (IUCN) in the World Conservation Strategy (WCS). The Strategy emphasised that the future development should focus on maintaining and sustainably using the ecological system [9].

Many countries have formulated the national conservation strategies since the WCS was developed. The initial concept of sustainable development was introduced in the conferences, since then the public starting to care about the environment, the evolution of sustainable development has brought.

In 1983, the UN established the World Commission on Environment and Development (WCED) and formulated 'A

Global Agenda for Change' to address concerns of environmental issues and human development in the world. Sustainability is clearly associated with environment protection but also extends to include the quality life. In 1987, the report of WCED 'Our Common Future', also known as the Brundtland Commission Report, first clearly defined 'sustainable development' and laid the foundation for the future of sustainable development [10]. The report made a clear statement that the Balance of the ecological environment must be taken into consideration during the development process, extending it to include social concerns (reductions of poverty and realisation of equality) as habitat conservation [11]. It encourages the international attention to focus on a development approach based on three considerations of economic growth, natural resource consumption and social satisfaction. And it illustrates that environment contribute to social and economic activities, the economic growth and social development cannot be improved with destroying the environment.

Since the WCED brought sustainability into public discourse with international discussions held for the human development problems. The significant milestone in the evolution of sustainability was the United Nations Conference on Environment and Development (UNCED) in Rio de Janeiro, 1992, also referred to the Rio Summit and Earth Summit, the largest international conference for discussing the solutions to the global problems. Several important agreements achieved in the conferences, the key outcomes are the Rio Declaration on Environment and Development and Agenda 21. The Rio Declaration proposes 27 principles for setting sustainable development policies, and Agenda 21 provides an action plan for sustainable development to deal with problems of human development and ecosystems [12]. These documents 'offers policies and programmes to achieve a sustainable balance between consumption, population and Earth's life-supporting capacity'. Agenda 21 has been considered as the comprehensive blueprint for sustainable development on the global, national and local levels, attempting to balance environmental protection with social and economic concerns [13].

The UN held the Rio+5 conference in 1997 and Rio+10 in 2002 to conduct the five-year and 10-year review of Rio decisions. In Rio+5, no new achievements had been made with little of implementation of Agenda 21. Rio+10 was held in 2002 in Johannesburg. The major outcome as the Johannesburg Declaration on Sustainable Development and agreements on environment problems [14] were achieved. The assembly described the attitude of some state governments to sustainable development as 'more talk than action', failing to recognise that all of states and individuals in the society have a responsibility for sustainable development.

In 2010, the Millennium Summit of the United Nations held established eight international development goals-The Millennium Development Goals (MDGs) which covered poverty, hunger, disease, unmet schooling, gender inequality and environmental degradation. The aim is through those goals to build a broad development vision for global action, and which are the requirements for whole sustainability [15].

In 2012, the head of states and high-level representatives held a conference in Rio de Janeiro, also known as 'Rio+20' twenty years after the milestone 1992 Earth Summit in Rio. This conference summarised the advances made over the previous two decades, but more important was to set the guidelines for next 10 to 20 years. The outcomes of 'The Future We Want' generates a guideline for achieving the sustainable future, draw the common vision as to ensure the promotion of an economically, socially and environmentally sustainability, and reaffirming commitment to each state to ensure full implementation of the past plans such as the Rio Declaration on Environment and Development and Agenda 21[16].

Through years' development, the term of sustainability has become an interdisciplinary science including ecology, economics, sociology, ethics, politics, etc. With the concept of sustainability gaining widespread recognition the term 'green' has become a new fashion, e.g. 'Green Economy', 'Green Growth', 'Green Industry' [16]. The emergence of 'green' is regarded as proving strategies and roadmaps for sustainable development in many countries [16]. It is developed on the basis of theories and practice of sustainable development and aims to increase lasting good of well-being.

Established through long-term practice and experience by many people, the idea of sustainable development has transitioned from being an interesting concept to an important 
international development direction [7]. A timeline of how the concept of sustainability has been developed is given in Table 2.1. It indicates that the global discussion moved forward to 'sustainable development' from 'environmental protection', the concept of sustainable development links poverty, inequality, environmental degradation and other problems associated with the development, and emphasise the relationships between economy, ecology and society. The concept has been transformed from academic research theory into common guidelines for policies building on human development from academic research theory.

TABLE I. Sustainable DEVElopMENT Process

\begin{tabular}{|c|c|c|}
\hline Year & Event & Outcomes \\
\hline \multicolumn{3}{|c|}{ Roots of Sustainability } \\
\hline $1950-1960 \mathrm{~s}$ & $\begin{array}{l}\text { Environmentalism } \\
\text { developed }\end{array}$ & $\begin{array}{l}\text { - People started being concerned with } \\
\text { environmental problems }\end{array}$ \\
\hline 1968 & $\begin{array}{l}\text { First } \\
\text { intergovernmental } \\
\text { conference by } \\
\text { UNESCO }\end{array}$ & $\begin{array}{l}\text { - Reconciled environment and } \\
\text { development } \\
\text { - Led to the creation of UNESCO's Man } \\
\text { and the Biosphere (MAB) Programme }\end{array}$ \\
\hline 1972 & $\begin{array}{l}\text { First United Nations } \\
\text { conference on the } \\
\text { environment, } \\
\text { Stockholm, Sweden }\end{array}$ & $\begin{array}{l}\text { Agreed the Stockholm Declaration } \\
\text { concerning the environment and } \\
\text { development } \\
\text { Established United Nations } \\
\text { Environment Programme (UNEP) to } \\
\text { provide leadership and partnership in } \\
\text { caring for the environment globally }\end{array}$ \\
\hline \multicolumn{3}{|c|}{ Emergence of Sustainability } \\
\hline 1987 & $\begin{array}{l}\text { World Commission on } \\
\text { Environment and } \\
\text { Development }\end{array}$ & $\begin{array}{l}\text { - First clearly defined 'sustainable } \\
\text { development' } \\
\text { - Promoted a framework of economic, } \\
\text { social and environmental criteria for } \\
\text { sustainable development }\end{array}$ \\
\hline 1992 & Rio Earth Summit & $\begin{array}{l}\text { Produced Agenda } 21 \text { for implementing } \\
\text { sustainable development globally } \\
\text { Analysed the impacts of human } \\
\text { activities on the environment and } \\
\text { provide guidance to manage them }\end{array}$ \\
\hline 1997 & Kyoto Protocol & $\begin{array}{l}\text { - Achieved first agreement to mandate } \\
\text { reductions in greenhouse-gas emissions } \\
\text { between nations } \\
\text { - Set the principle of common but } \\
\text { differentiated responsibilities to allocate } \\
\text { responsibilities to developed nations }\end{array}$ \\
\hline 2000 & $\begin{array}{l}\text { United Nations } \\
\text { Millennium Summit }\end{array}$ & $\begin{array}{l}\text { Set Millennium Development Goals } \\
\text { (MDGs), covering issues of poverty } \\
\text { eradication, environmental protection, } \\
\text { human rights and protection of the } \\
\text { vulnerable. }\end{array}$ \\
\hline 2002 & $\begin{array}{l}\text { Rio+10, Johannesburg } \\
\text { Summit }\end{array}$ & $\begin{array}{l}\text { Considered problems of poverty } \\
\text { eradication, consumption and } \\
\text { production issues, and health concerns } \\
\text { Launch of partnerships in a new form, } \\
\text { involving civil society and not just } \\
\text { governments, aimed at implementing } \\
\text { sustainable development }\end{array}$ \\
\hline 2009 & $\begin{array}{l}\text { UN Climate Change } \\
\text { Conference, } \\
\text { Copenhagen }\end{array}$ & $\begin{array}{l}\text { - Formed formal decisions by consensus } \\
\text { on climate changes }\end{array}$ \\
\hline 2012 & $\begin{array}{l}\text { Rio }+20 \text {, Rio de } \\
\text { Janeiro, Brazil }\end{array}$ & $\begin{array}{l}\text { - Signed agreement on build a green } \\
\text { economy to achieve sustainable } \\
\text { development and lift people out of } \\
\text { poverty; and improve international } \\
\text { coordination for sustainable } \\
\text { development }\end{array}$ \\
\hline
\end{tabular}

The timeline shows milestones across the history of sustainable development, it indicates that the global discussion moved forward to 'sustainable development' from 'environmental protection'. The concept of sustainable development links poverty, inequality, environmental degradation and other problems associated with development, and emphasises the relationships between economy, ecology and society. At the same time, the concept has been transformed from academic research theory into common guidelines for policies building on human development.

\section{B. Definition of sustainability}

With increasing awareness of sustainability, debates about its definition have arisen from different disciplines and perspectives including ecology, economics, sociology biology and so on [17]. The concept of sustainability is given different interpretations by way of different perspectives. Many researchers argue that precisely defining sustainability has been considered a complex task, the meaning of the term often appears to be unclear and ambiguous [18]

Another question has arisen when people are trying to define the terms of sustainability and sustainable development: do they mean the same thing? Johnston et al. considered sustainability as the basis of sustainable development in international discussions[19]. Blewitt argued that 'sustainable development' is preferred and described the development process to realise the goal of 'sustainability' [20]. According to Dresner, sustainability primarily concentrates on environmental issues, and sustainable development is focused on development methods. But many studies do not show any distinct differences between them. In most of the international conferences and documents such as the Brundtland Commission Report and Agenda 21, these two terms are used interchangeably [2]. The implication of this, at least for most researchers, is that sustainable development is the route to achieving true sustainability, with both terms being used interchangeably to describe the comprehensive approach required.

Sustainable development has its origins in the effort to protect ecology, and as an alternative to the traditional development pattern where increased material wealth damages the environment and natural resources [21]. It is used to investigate the relationship and interaction between human activities and the ecological environment [22]. According to Rogers et al. , sustainability means 'maintain the resilience and robustness of biological and physical systems' which indicates that the development should not overwhelm the carrying capacity of the earth[23].

In practice, economic growth has traditionally been the priority of development with the objectives of increasing production, profit and materials, and driving social-economic transformation [24]. From this perspective, sustainability is considered a more balanced approach to maximising economic income while maintaining or increasing the stock of capital. People in poverty will tend to take care of the environment when their per capita income rises, and then they will start to divert income to achieve sustainable development through the production of superior goods and services [23]. 'Sustainable development involves devising a social and economic system, which ensures that these goals are sustained, i.e. that real incomes rise, that educational standards increase, that the health of the nation improves, that the general quality of life is advanced' [25]

There is an increasing recognition that development also carries a connotation to include improving human health, 
quality of life and how to obtain the necessary resources, and create a more equal community[21] (Fan and Jiang, 2015). The World Conservation Union (IUCN) and United Nations Environment Programme (UNEP) defined sustainable development from humanity's perspective as 'development which improves the quality of human life while living within the carrying capacity of supporting eco-systems' [26]. And the most widely accepted definitions of sustainable development in the Brundtland Report emphasises that 'sustainable development is development that meets the needs of the present without compromising the ability of future generations to meet their own needs, in which every human being has the opportunity to develop in freedom, within a balanced society and in harmony with the environment' [10].

The definition from WCED draws the link between the economy, environment and social well-being, a healthy economy requiring a healthy environment, and human beings' activities directly influencing the environment (Johnston et al., 2007). It transmits a message with various considerations: equality between present and future generations, poverty within the current generation and balance between using national resources and environmental systems restoration [18].

Sustainability is now accepted including economic, social and ecological viewpoints, from a technological perspective people cannot embark upon further development without appropriate technology to support it[27]. Therefore, sustainable development works towards cleaner and more efficient technology, closer to zero emissions, as far as possible, to reduce the consumption of energy and other natural resources[28]. Strong offered a definition as 'sustainable development involves a process of deep and profound change in the political, social, economic, institutional, and technological order, including the redefinition of relations between developing and more developed countries.' [29]

Various definitions contribute to clarification of the term sustainability but they can be open to interpretation. Bolis et al argued that the concept of sustainability means different things to different people [30]. This is at least partly due to the variation of economic, social and ecological conditions in different locations and situations, influencing how different nations set their development priorities. Some governments focus on human development to improve human literacy and life expectancy, but others would concentrate on reducing poverty and solving other social problems [31]. Hence, IUCN and UNCP declared that nations can set up different development goals according to their own circumstances [26].

Integrating the varied interpretations and definitions derived from different perspectives, sustainability can be considered as guidance for development to ensure the future survival and advancement of humans. It provides a holistic approach to economic development, takes scientific and technological progress as a given, provides for the development of individuals and social cohesiveness to realise justice between inter-generation and intra-generation, and being in harmony between human beings and the ecoenvironment under the real conditions and circumstances of a region or nation.
However, there is no precise definition of 'sustainable development', and the debate about this concept is continuing. The international community must go well beyond the general considerations on social, economic and environmental issues, and advance a more holistic and integrated meaning of development.

\section{CONCLUSION}

The 2030 Agenda, adopted at the UN Sustainable Development Summit in 2015, sets out the direction for the development of countries and for international development cooperation. As a development-oriented agenda, it embodies the aspirations of our peoples for a better life and facilitates the efforts in tackling global risks and challenges. The Initiative focuses on policy synergy, infrastructure development, unimpeded trade, financial cooperation and people-to-people bond, which are intrinsically linked to the Sustainable Development Goals. The synergy between the BRI and the 2030 Agenda has already been formed in promoting sustainable development. since the term 'sustainability' was clearly defined in 1987, and research of the concept has achieved great significance and has become widely accepted, but it remains controversial because proper comprehension of the term can be challenging. The paper revealed that there are hundreds of definitions, each emphasising different aspects of sustainability, although the basic dimensions of economic, social and environmental development are generally accepted internationally.

\section{ACKNOWLEDGMENT}

I gratefully thank the Dr. Stuart Allan from the University of Greenwich for his useful comments and kind help.

\section{REFERENCES}

[1] Development Research Centre of the State Council. Advancing Global Sustainable Development Through High-quality Belt and Road Cooperation. Remarks by Zhang Jun at the Seminar on Advancing Sustainable Development Goals with the Belt and Road Cooperation. May 2019.

[2] Dresner, S. The Principles of Sustainability. 2nd ed. London: Routledge. 2008 .

[3] Niu, W. Y. Theory and Practice of China's Sustainable Development. Bulletin of Chinese Academy of Sciences, 26(3), p. 78. $2012 \mathrm{a}$.

[4] Wang, J. The Indicator System of Regional Sustainable Development and the Evaluating Model. A Case Study of Changsha City Hunan Province. Chinese Journal of Management Science, 8(2).pp55-57.2000

[5] Meadows, D., Randers, J. and Behrens, W. The Limits to Growth. New York: Universe Books. 1972.

[6] United Nations. A Comprehensive Guide for Social Impact Assessment. 2006.

[7] United Nations. The Sustainable Development Goals Report 2019.

[8] Handl, G. Declaration of the United Nations Conference on the Human Environment (Stockholm Declaration), 1972 and the Rio Declaration on Environment and Development, 1992. United Nations Audiovisual Library of International Law, 11. 2012.

[9] International Union for Conservation of Nature., Natural Resources. and World Wildlife Fund. World Conservation Strategy: Living Resource Conservation for Sustainable Development. Gland, Switzerland: IUCN. 1980. 
[10] World Commission on Environment and Development. Our Common Future. New York: Oxford University Press. 1987.

[11] Zhu, H., Cai, D. and Zhang, Q. The Overview of Sustainable Development Concepts in China. Shangyeshidai, 7, pp.36-38.2011

[12] United Nations Conference on Environment and Development. United Nations Conference on Environment \& Development Rio De Janerio, Brazil, 3 - 14 June 1992. Agenda 21. 1992

[13] Niu, W. Y. The Cognition of Sustainable Development Content. China Population, Resources and Environment, 2(5), pp. 55-56. 2012b

[14] United Nations. Un General Assembly Creates Key Group on Rio+20 Follow-up Group to Work on Design of New Sustainable Development Goals. In: Rio+ 20 United Nations Conference on Sustainable Development, June 2012.

[15] Sachs, J. D. From Millennium Development Goals to Sustainable Development Goals. The Lancet, 379(9832), pp.2206-2211.2012

[16] United Nations Educational, Scientific and Cultural Organization. The Crucial Role of Science for Sustainable Development and the Post 2015 Development Agenda.

[17] Bolis, I., Morioka, S. N. and Sznelwar, L. I. When Sustainable Development Risks Losing Its Meaning. Delimiting the Concept with a Comprehensive Literature Review and a Conceptual Model. Journal of Cleaner Production, 83, pp.7-20.2014.

[18] Wuelser, G., Pohl, C. and Hadorn, G. H. Structuring Complexity for Tailoring Research Contributions to Sustainable Development: A Framework. Sustainability Science, 7(1), pp.81-93.2012.

[19] Johnston, P., Everard, M., Santillo, D. and Robèrt, K. Reclaiming the Definition of Sustainability. Environmental Science and Pollution Research International, 14(1), pp.60-66.2007.

[20] Blewitt, J. Understanding Sustainable Development. London: Routledge.2014.

[21] Fan, J. and Jiang, Z. Trend of Human-Economic Geography in Relation to the Future Earth Initiative for Systemic Solutions of Regional Sustainable Development. Progress in Geography, 34(1), pp.1-9.2015.
[22] Sun, M. Green Building Design Based on the Idea of Sustainable Development: Take Suzhou Phoenix International Bookstore Project as an Example. Chinese \& Overseas Architecture, 8, pp.110-115.2016.

[23] Rogers, P. P., Jalal, K. F. and Boyd, J. A. An Introduction to Sustainable Development. Harvard University Press.2006.

[24] Pieterse, J. N. Development Theory: Deconstructions/Reconstructions. 2nd ed. London: SAGE Publication.2009.

[25] Pearce, D., Markandya, A. and Barbier, E. B. Blueprint for a Green Economy, a Report Prepared for the UK Department of Environment. London: Earthscan Publishers Ltd.1989.

[26] International Union for Conservation Of Nature, United Nations Environment Programme. Caring for the Earth: A Strategy for Sustainable Living. Gland, Switzerland, October 1991.

[27] Hill, R. C. and Bowen, P. A. Sustainable Construction: Principles and a Framework for Attainment. Construction Management \& Economics, 15(3), pp.223-239. 1997.

[28] United Nations Environment Programme. The Emissions Gap Report a Unep Synthesis Report 2014. United Nations Environment Programme (UNEP). November 2014.

[29] Strong, M. Required Global Changes: Close Linkages between Environment and Development. In: U. Kirdar (ed). Change: Threat or Opportunity for Human Progress. Ecological Change.New York: United Nations.1992

[30] Bolis, I., Morioka, S. N. and Sznelwar, L. I. When Sustainable Development Risks Losing Its Meaning. Delimiting the Concept with a Comprehensive Literature Review and a Conceptual Model. Journal of Cleaner Production, 83, pp.7-20.2014.

[31] World Bank. Beyond Economic Growth: An Introduction to Sustainable Development. 2nd Ed. Washington, DC: The World Bank.2004. 